Article

\title{
Mechanistic Insights into Visible Light-Induced Direct Hydroxylation of Benzene to Phenol with Air and Water over Pt-Modified $\mathrm{WO}_{3}$ Photocatalyst
}

\author{
Yuya Kurikawa ${ }^{1}$, Masahiro Togo ${ }^{1}$, Michihisa Murata ${ }^{1}{ }^{1}$, Yasuaki Matsuda ${ }^{1}$, \\ Yoshihisa Sakata ${ }^{2} \mathbb{1}$, Hisayoshi Kobayashi ${ }^{3}$ and Shinya Higashimoto ${ }^{1, *}$ \\ 1 Department of Applied Chemistry, Faculty of Engineering, Osaka Institute of Technology, 5-16-1 Omiya, \\ Asahi-ku, Osaka 535-8585, Japan; m1m19508@st.oit.ac.jp (Y.K.); m1m19515@st.oit.ac.jp (M.T.); \\ michihisa.murata@oit.ac.jp (M.M.); yasuaki.matsuda@oit.ac.jp (Y.M.) \\ 2 Graduate School of Science and Technology for Innovation, Yamaguchi University, 2-16-1 Tokiwadai, \\ Ube 755-8611, Japan; yoshi-sa@yamaguchi-u.ac.jp \\ 3 Department of Chemistry and Materials Technology, Kyoto Institute of Technology, Matsugasaki, Sakyo-ku, \\ Kyoto 606-8585, Japan; hisabbit@yahoo.co.jp \\ * Correspondence: shinya.higashimoto@oit.ac.jp; Tel.: +81-(0)6-6954-4283
}

Received: 2 May 2020; Accepted: 15 May 2020; Published: 18 May 2020

\begin{abstract}
Activation of $\mathrm{C}(\mathrm{sp} 2)-\mathrm{H}$ in aromatic molecules such as benzene is one of the challenging reactions. The tungsten trioxide supported $\mathrm{Pt}$ nanoparticles $\left(\mathrm{Pt}-\mathrm{WO}_{3}\right)$ exhibited hydroxylation of benzene in the presence of air and $\mathrm{H}_{2} \mathrm{O}$ under visible-light $(420<\lambda<540 \mathrm{~nm})$ irradiation. The photocatalytic activities (yields and selectivity of phenol) were studied under several experimental conditions. Furthermore, investigations of mechanistic insight into hydroxylation of benzene have been carried out by analyses with apparent quantum yields (AQY), an $\mathrm{H}_{2}{ }^{18} \mathrm{O}$ isotope-labeling experiment, kinetic isotope effects (KIE), electrochemical measurements and density functional theory (DFT) calculations. It was proposed that dissociation of the $\mathrm{O}-\mathrm{H}$ bond in $\mathrm{H}_{2} \mathrm{O}$ is the rate-determining step. Furthermore, the substitution of the $\mathrm{OH}$ derived from $\mathrm{H}_{2} \mathrm{O}$ with $\mathrm{H}$ abstracted from benzene by photo-formed $\mathrm{H}_{2} \mathrm{O}_{2}$ indicated a mechanism involving a push-pull process for the hydroxylation of benzene into phenol.
\end{abstract}

Keywords: $\mathrm{Pt}_{-}-\mathrm{WO}_{3}$ photocatalyst; visible light; hydroxylation of benzene; phenol formation; isotope $\mathrm{H}_{2}{ }^{18}$ O-labeling

\section{Introduction}

Visible light-driven photocatalysts for environmental conservation, securing energy resources and selective organic synthesis have received considerable attention because they can utilize unlimited solar energy [1-7]. Tungsten trioxide $\left(\mathrm{WO}_{3}\right)$ is one of the promising visible-light responsible photocatalyst having a direct band-gap excitation at ca. $2.7 \mathrm{eV}$. Recently, $\mathrm{WO}_{3}$ has been proven to be an effective strategy for improving the photocatalytic degradation of volatile organic compounds (VOCs) such as acetaldehyde [8-11], toluene [12], acid [13]; water splitting to form $\mathrm{O}_{2}$ in the presence of sacrificial agent [1]; as well as selective organic conversion such as oxidation of alcohol [14].

Phenols are important precursors for many chemicals and industrial products such as dyes and polymers, and they are currently produced from benzene by a three step cumene process. The cumene process for phenol formation exhibits low activity ( $5 \%$ yield of phenol) and emission of large amounts of waste although the reactions require high temperature, high pressure and strong acidic conditions. Therefore, it is a great challenge to develop a one-step synthesis of phenol from benzene by using homogeneous and heterogeneous inorganic catalysts such as palladium membrane, titanium-containing 
mesoporous molecular sieves and vanadium-substituted phosphomolybdate by hydrogen peroxide $\left(\mathrm{H}_{2} \mathrm{O}_{2}\right)$ [15-17]. Although $\mathrm{H}_{2} \mathrm{O}_{2}$ is often used as environmentally friendly oxidant only to produce $\mathrm{H}_{2} \mathrm{O}$ in catalytic hydroxylation of benzene, $\mathrm{O}_{2}$ is more ideal oxidant than $\mathrm{H}_{2} \mathrm{O}_{2}$ due to its abundance in nature.

In a recent study, one-step direct hydroxylation of benzene toward phenol has been extensively studied using homogeneous photocatalysts such as quinolinium ions and $\left[\mathrm{Ru}^{\mathrm{II}}\left(\mathrm{Me}_{2} \mathrm{phen}\right)_{3}\right]^{2+}$ ions, [18-21], and heterogeneous semiconductor photocatalyst such as $\mathrm{TiO}_{2}$ [22-27] and $\mathrm{WO}_{3}$ [28,29] have been employed for selective photocatalytic hydroxylation of benzene to phenol under photo-irradiation ultraviolet (UV) light and/or visible-light. Yoshida et al. previously reported that platinum (Pt)-loaded $\mathrm{TiO}_{2}\left(\mathrm{Pt}-\mathrm{TiO}_{2}\right)$ photocatalyst exhibited direct hydroxylation of benzene to form phenol and $\mathrm{H}_{2}$ in the absence of $\mathrm{O}_{2}$ under UV-light irradiation [22]. Also, Tomita et al. reported that the Pt-deposited $\mathrm{WO}_{3}\left(\mathrm{Pt}-\mathrm{WO}_{3}\right)$ photocatalyst exhibited selective hydroxylation of benzene to phenol in the presence of $\mathrm{O}_{2}$ and $\mathrm{H}_{2} \mathrm{O}$ under light irradiation of both UV light and visible light $(300<\lambda<500 \mathrm{~nm})[28,29]$. It was also confirmed that $\mathrm{OH}$ derived from $\mathrm{H}_{2} \mathrm{O}$ is included in phenol by employing an $\mathrm{H}_{2}{ }^{18} \mathrm{O}$ labeling experiment [29]. However, in a previous study, photocatalytic activities and reaction mechanisms for hydroxylation of benzene on the $\mathrm{Pt}-\mathrm{WO}_{3}$ have not been demonstrated under only irradiation of visible-light $(\lambda>420 \mathrm{~nm})$.

In this study, we focus on understanding the photocatalytic activities for hydroxylation of benzene on the $\mathrm{Pt}-\mathrm{WO}_{3}$ photocatalyst under irradiation of only visible light $(420<\lambda<540 \mathrm{~nm})$. Furthermore, investigation of mechanistic insight has been carried out by combination with apparent quantum yields (AQY), $\mathrm{H}_{2}{ }^{18} \mathrm{O}$ isotope labeling experiment, kinetic isotope effects $\left(\mathrm{C}_{6} \mathrm{D}_{6}, \mathrm{D}_{2} \mathrm{O}\right)$, electrochemical measurements and density functional theory (DFT) calculations.

\section{Results}

\subsection{Preparation of Pt-Deposited Tungsten Trioxide $\left(\mathrm{WO}_{3}\right)$ and Its Characterization}

The $\mathrm{Pt}-\mathrm{WO}_{3}$ photocatalyst was characterized by X-ray diffraction (XRD), ultraviolet-visible (UV-Vis) spectroscopy, scanning transmittance electron microscope with energy-dispersed X-ray emission spectroscopy (STEM-EDS) and X-ray photoelectron spectroscopy (XPS) measurements. The XRD patterns of $\mathrm{WO}_{3}$ and $\mathrm{Pt}-\mathrm{WO}_{3}$ were identified with a monoclinic structure in accordance with standard XRD profile of JCPDS cards No. 43-1035, and no other phase of Pt species was observed (see Figure $1[\mathrm{I}]$ ). The $\mathrm{WO}_{3}$ exhibited absorption spectrum in the visible-light region. Bandgap of the $\mathrm{WO}_{3}$ was estimated to be ca. $2.6 \mathrm{eV}$ from tauc plots vof $(F(\mathrm{R}) \times h v)^{2}$ vs. $h v$ (See Figure S1). Furthermore, the $\mathrm{Pt}-\mathrm{WO}_{3}$ with different amounts of $\mathrm{Pt}$ species exhibited optical absorbance above 450 $\mathrm{nm}$, which is attributable to the scattering effects from the Pt particles [30] or surface resonance [31]. The optical absorbance significantly increased as an increase of the Pt species deposited on the $\mathrm{WO}_{3}$ (See Figure 1 [II]). The scanning transmittance electron microscope with the STEM-EDS image of $\mathrm{Pt}(0.4)-\mathrm{WO}_{3}$ confirmed that Pt nano-particles were dispersed on the $\mathrm{WO}_{3}$ surface (See Figure 1 [III]). The XPS analysis indicated that the $\mathrm{Pt}(0.4)-\mathrm{WO}_{3}$ photocatalyst was observed to possess two different types of doublet peaks $\left(4 \mathrm{f}_{5 / 2}\right.$ and $\left.4 \mathrm{f}_{7 / 2}\right)$ at 74.8 and $71.6 \mathrm{eV}$ for $\mathrm{Pt}^{0}$ as a major species, at 75.8 and $72.5 \mathrm{eV}$ for $\mathrm{Pt}^{2+}$ as a minor species (See Figure 1 [IV]). These results indicated that Pt nano-particle deposition on the $\mathrm{WO}_{3}$ was successfully performed by photo-electrochemical deposition methods. 

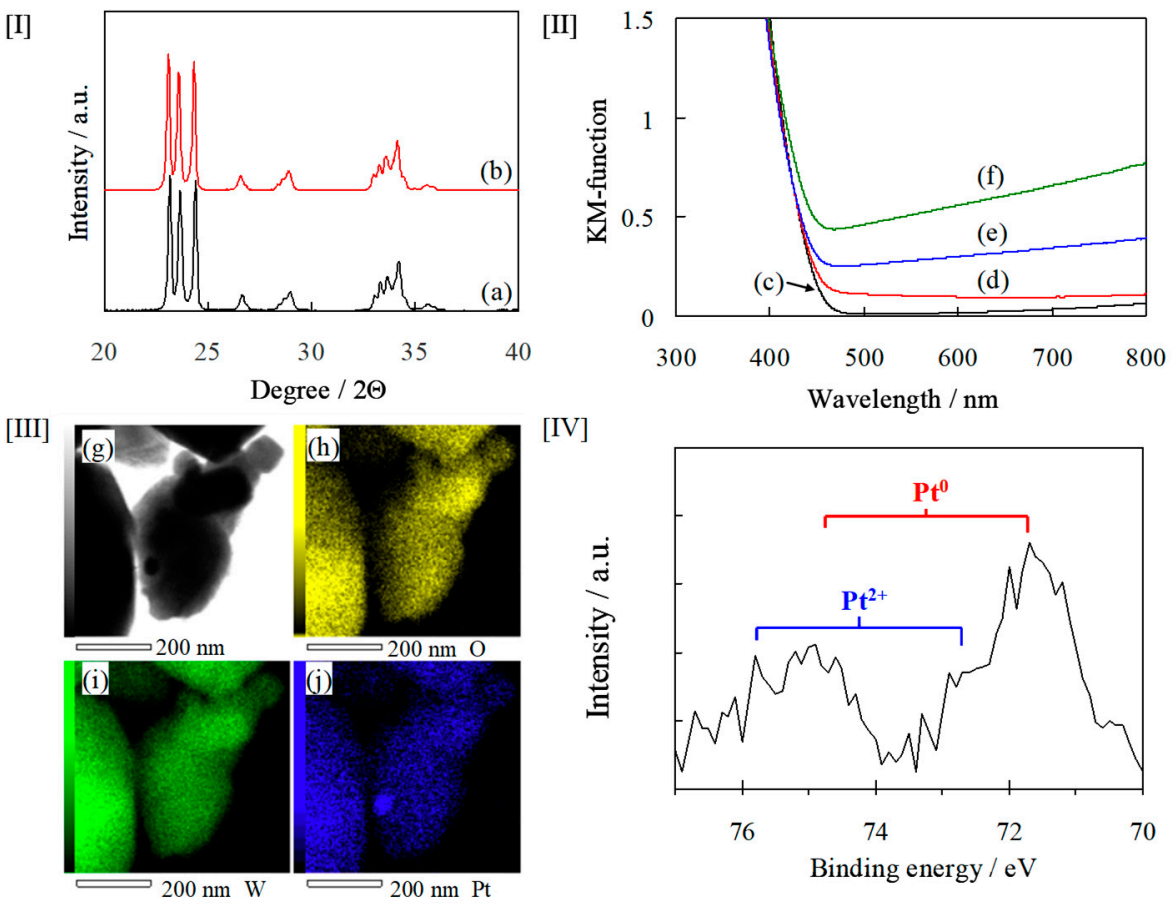

Figure 1. X-ray diffraction $(\mathrm{XRD})$ patterns $[\mathrm{I}]$ of tungsten trioxide $\left(\mathrm{WO}_{3}\right)$ (a) and $\mathrm{Pt}(0.4)-\mathrm{WO}_{3}$ (platinum-tungsten trioxide) (b); ultraviolet-visible (UV-Vis) absorption spectra [II] of $\mathrm{WO}_{3}$ (c), $\mathrm{Pt}(0.1)-\mathrm{WO}_{3}(\mathrm{~d}), \mathrm{Pt}(0.2)-\mathrm{WO}_{3}(\mathrm{e}), \mathrm{Pt}(0.4)-\mathrm{WO}_{3}$ (f); scanning transmittance electron microscope (STEM) image (g) and energy-dispersed X-ray emission spectroscopy (EDS) (h-j) [III] of the $\mathrm{Pt}(0.4)-\mathrm{WO}_{3}: \mathrm{O}(\mathrm{h})$, W (i) and Pt (j); and XPS [IV] of Pt (4f) of the Pt(0.4)-WO

\subsection{Photocatalytic Hydroxylation of Benzene on the $\mathrm{Pt}_{-} \mathrm{WO}_{3}$ under Visible-Light Irradiation}

The photocatalytic hydroxylation of benzene in the presence of air and $\mathrm{H}_{2} \mathrm{O}$ was performed on the $\mathrm{WO}_{3}$ photocatalyst under visible-light irradiation. It was confirmed that the hydroxylation reaction does not take place under photo-irradiation without a photocatalyst nor with a photocatalyst without irradiation, i.e., both photocatalyst and irradiation are required in combination for hydroxylation reaction to occur. The $\mathrm{WO}_{3}$ exhibited very low activity for phenol formation under visible-light irradiation (See Table S1). After the photocatalytic reaction, the color of suspension was slightly bluish, suggesting that the $\mathrm{WO}_{3}$ was partially reduced and the ability for oxygen reductive reaction (ORR) was retarded. On the other hand, $\mathrm{Pt}_{-} \mathrm{WO}_{3}$ exhibited significant improvement of photocatalytic activities for the formation of hydroxylated products such as phenol and catechol. The yields of phenols significantly improved as an increase of loading amounts of Pt species up to 0.2 atom $\%$, and the activity was saturated at 0.4 atom $\%$. The selectivity of phenol was optimized at 0.1 atom $\%$ and then slightly decreased as an increase of Pt-deposition (see Figure 2 [I], Table S1). Reaction time profile for phenol evolution on the $\mathrm{Pt}(0.2)-\mathrm{WO}_{3}$ photocatalyst was shown in Figure 2 [II]. The photocatalytic activity increased as an increase of reaction time: producing $29 \mu \mathrm{mol}$ of phenol with $47 \%$ selectivity after photocatalytic reaction for $20 \mathrm{~h}$, and $40 \mu \mathrm{mol}$ phenol with $64 \%$ selectivity for $70 \mathrm{~h}$. (See distribution of side products shown in Table S2). After the reaction for $70 \mathrm{~h}$, the amount of photo-formed $\mathrm{H}_{2} \mathrm{O}_{2}$ was only $0.15 \mu \mathrm{mol}$, which are much less than hydroxylated products assuming two electron reduction of $\mathrm{O}_{2}$ to form $\mathrm{H}_{2} \mathrm{O}_{2}$. It can be considered that the $\mathrm{H}_{2} \mathrm{O}_{2}$ may be self-decomposed on the photocatalyst and/or participate in the reaction for the hydroxylation of benzene. The role of $\mathrm{H}_{2} \mathrm{O}_{2}$ will be discussed later. Moreover, when the volume of solvent in the reaction became small, the yields of phenol decreased, while the selectivity of phenol improved over $70 \%$ (See Table S3). Therefore, a trade-off relation between the yields and selectivity of phenol was observed. The surface coverage of the photocatalyst by condensation of the adsorbent could be considered to prevent over oxidation of benzene leading 
to high selectivity of phenol, of which the similar phenomena was previously reported on the $\mathrm{TiO}_{2}$ photocatalyst [25].

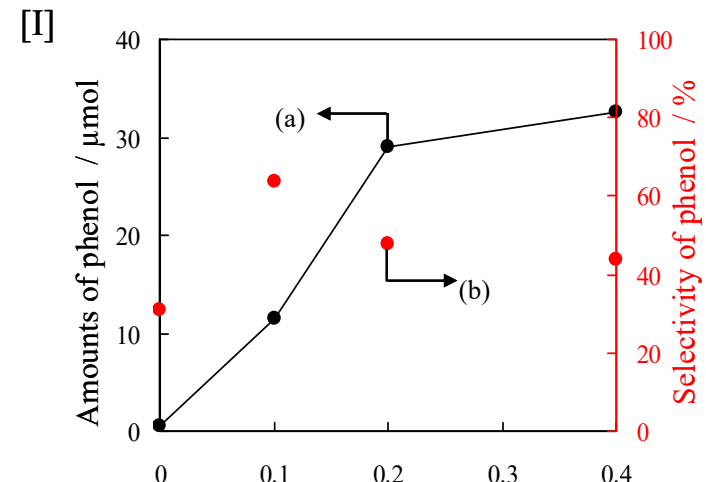

Amounts of $\mathrm{Pt}$ added to $\mathrm{WO}_{3} /$ atomic\%

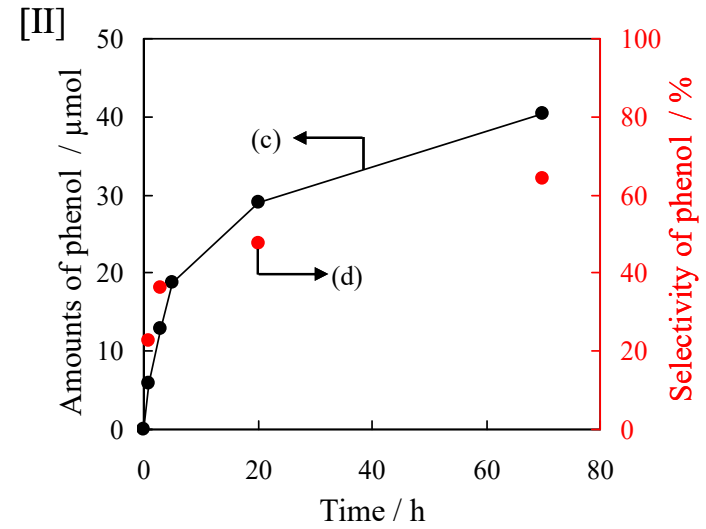

Figure 2. Dependence of loading amounts of $\mathrm{Pt}$ deposited on the $\mathrm{WO}_{3}$ [I]; and reaction time profile on the $\mathrm{Pt}(0.2)-\mathrm{WO}_{3}[\mathrm{II}]$ for hydroxylation of benzene to form phenol (yields: a, c; and selectivity: $\mathrm{b}$ and $\mathrm{d}$ ) under visible-light irradiation.

Apparent quantum yields (AQY) on the $\mathrm{Pt}(0.2)-\mathrm{WO}_{3}$ were measured. Assuming one photon producing one phenol, the AQY for phenol formation reached over $2 \%$ by excitation at $400 \mathrm{~nm}$ as shown in Figure 3. The AQY profile was found to be very similar with the absorption spectrum of $\mathrm{WO}_{3}$, suggesting that phenol formation is strongly correlated with the light absorbance of $\mathrm{WO}_{3}$, not with $\mathrm{Pt}$ scattering [30] and/or resonance absorbance [31].

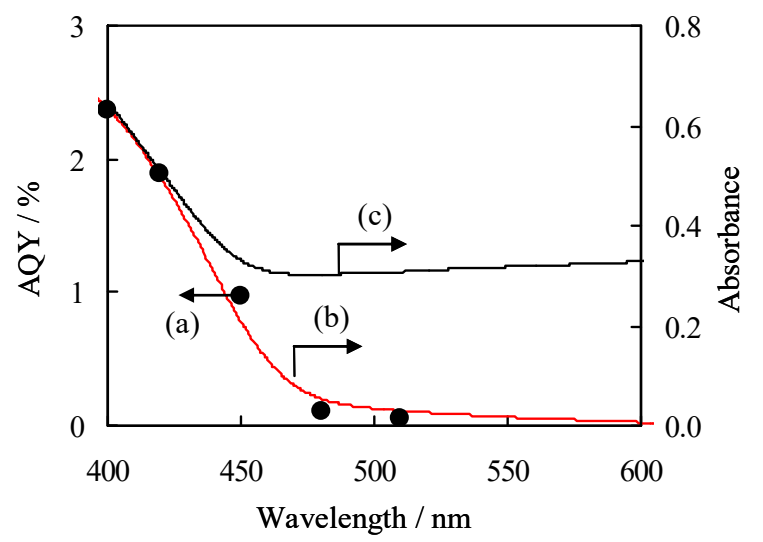

Figure 3. Dependence of wavelength photo-irradiated on apparent quantum yields, AQY (a) for hydroxylation of benzene to phenol, and UV-Vis absorbance of $\mathrm{WO}_{3}$ (b) and $\mathrm{Pt}(0.2)-\mathrm{WO}_{3}$ (c).

\subsection{Role of $\mathrm{H}_{2} \mathrm{O}$ on the Photocatalytic Reactions}

In order to understand role of $\mathrm{H}_{2} \mathrm{O}$, the $\mathrm{H}_{2}{ }^{18} \mathrm{O}$-labeling experiments for photocatalytic hydroxylation of benzene were performed by liquid chromatography-mass spectrometry (LC-MS), and results are shown in Table 1 and Figure S2. It is noted that the atomic exchanges between $\mathrm{O}_{2}$ and $\mathrm{H}_{2} \mathrm{O}$, and between $\mathrm{O}_{2}$ and phenol are very slow even under photo-irradiation [23,32]. Therefore, $\mathrm{H}_{2}{ }^{18} \mathrm{O}$ was used for tracing $\mathrm{O}$ species incorporated in phenol. When the photocatalytic reactions were carried out in the presence of $\mathrm{H}_{2}{ }^{16} \mathrm{O}(100 \%)$, the photo-formed phenol was only observed at the mass number of $93(\mathrm{~m} / \mathrm{z})$, which is attributed to the phenolic anion $\left(\mathrm{C}_{6} \mathrm{H}_{5}{ }^{16} \mathrm{O}^{-}\right)$. Furthermore, when the photocatalytic reactions by employing $\mathrm{H}_{2}{ }^{16} \mathrm{O}(90 \%) / \mathrm{H}_{2}{ }^{18} \mathrm{O}(10 \%)$ were carried out, the peaks at $93(\mathrm{~m} / \mathrm{z})$ for the $\mathrm{C}_{6} \mathrm{H}_{5}{ }^{16} \mathrm{O}^{-}$as well as $95(\mathrm{~m} / \mathrm{z})$ for $\mathrm{C}_{6} \mathrm{H}_{5}{ }^{18} \mathrm{O}^{-}$were observed. The peak intensities indicated that the ratio of ${ }^{18} \mathrm{O}$ to ${ }^{16} \mathrm{O}$ involved in the photo-formed phenol was $9.9 \%$ under visible-light 
$(420<\lambda<540 \mathrm{~nm})$, while $9.1 \%$ under UV-light irradiation $(300<\lambda<400 \mathrm{~nm})$. Assuming that $\mathrm{H}_{2}{ }^{16} \mathrm{O}$ and $\mathrm{H}_{2}{ }^{18} \mathrm{O}$ exhibited same activity for hydroxylation of benzene, it was concluded that hydroxyl groups in phenol is almost derived from $\mathrm{H}_{2} \mathrm{O}$ under both irradiation of visible-light and UV-light.

Table 1. $\mathrm{H}_{2}{ }^{18} \mathrm{O}$ isotope labeling test for photocatalytic hydroxylation of benzene on the $\mathrm{Pt}(0.2)-\mathrm{WO}_{3}$.

\begin{tabular}{|c|c|c|c|c|c|c|c|c|}
\hline \multirow{2}{*}{ Entry } & \multicolumn{7}{|c|}{ Products/ $\mu \mathrm{mol}$} & \multirow{2}{*}{$\begin{array}{c}{ }^{18} \mathrm{O} /{ }^{16} \mathrm{O}^{1} \text { Ratios } \\
\text { in Phenol/\% }\end{array}$} \\
\hline & PH & RE & BQ & CA & HQ & PL & PG & \\
\hline 1 & 22.0 & 1.4 & 0.01 & 4.3 & 0.1 & 3.4 & 1.9 & 9.9 \\
\hline 2 & 18.0 & 0.4 & 0.03 & 5.9 & 1.3 & 5.5 & 1.7 & 9.1 \\
\hline
\end{tabular}

${ }^{1} \mathrm{H}_{2}{ }^{16} \mathrm{O}(90 \%) / \mathrm{H}_{2}{ }^{18} \mathrm{O}(10 \%)(5 \mathrm{~mL})$, benzene: $300 \mu \mathrm{mol}$, visible-light irradiation (entry 1) and UV-light irradiation (entry 2) for $20 \mathrm{~h}$. Abbreviation: phenol (PH), resolcinol (RE), $p$-benzoquinone (BQ), catechol (CA), hydroquinone (HQ), phloroglucinol (PL), pyrogallol (PG).

The rate determining step for hydroxylation of benzene was investigated by the kinetic isotope effect (KIE) using $\mathrm{D}_{2} \mathrm{O}$ and $\mathrm{C}_{6} \mathrm{D}_{6}$ (See Figure 4). The reaction rate constants for formation of phenol from normal benzene $\left(\mathrm{C}_{6} \mathrm{H}_{6}\right)$ in the presence of $\mathrm{H}_{2} \mathrm{O}$ and $\mathrm{D}_{2} \mathrm{O}$ were roughly estimated to be $3.75 \times 10^{-6}$ and $1.42 \times 10^{-6} \mathrm{~s}^{-1}$ for $(\mathrm{a})$ and $(\mathrm{b})$, respectively. The kinetic isotope effect $\left(k_{\mathrm{H} 2 \mathrm{O}} / k_{\mathrm{D} 2 \mathrm{O}}\right)$ was estimated to be ca. 2.7 (see Figure 4 [I]). On the other hand, the reaction rate constants for formation of phenol from $\mathrm{C}_{6} \mathrm{H}_{6}$ and $\mathrm{C}_{6} \mathrm{D}_{6}$ in the presence of $\mathrm{H}_{2} \mathrm{O}$ were roughly estimated to be $3.75 \times 10^{-6}$ and $3.77 \times 10^{-6} \mathrm{~s}^{-1}$ for (c) and (d), respectively. That is, the KIE of $k_{\mathrm{C} 6 \mathrm{H} 6} / k_{\mathrm{C} 6 \mathrm{D} 6}$ was estimated to be 1.0 (see Figure 4 [II]). These results suggest that the dissociation of $\mathrm{O}-\mathrm{H}$ bond in the $\mathrm{H}_{2} \mathrm{O}$ plays an important role in the rate determining step for the hydroxylation of benzene.
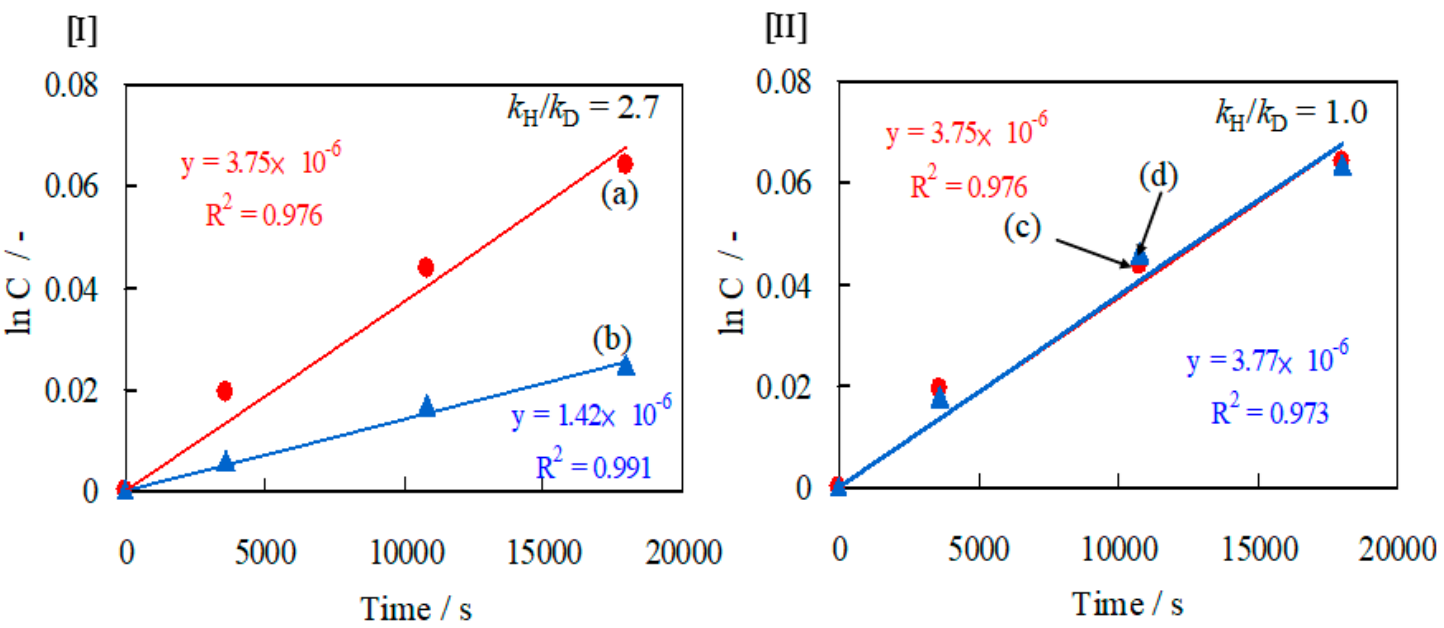

Figure 4. Kinetic isotope effects (KIE) on photocatalytic hydroxylation of benzene in the presence of air and $\mathrm{H}_{2} \mathrm{O}$ on $\mathrm{Pt}(0.2)-\mathrm{WO}_{3}(20 \mathrm{mg})$ under visible light irradiation. Hydroxylation of $\mathrm{C}_{6} \mathrm{H}_{6}$ in the presence of $\mathrm{H}_{2} \mathrm{O}(\mathrm{a})$ and $\mathrm{D}_{2} \mathrm{O}(\mathrm{b})[\mathrm{I}]$; and that of $\mathrm{C}_{6} \mathrm{H}_{6}(\mathrm{c})$ and $\mathrm{C}_{6} \mathrm{D}_{6}(\mathrm{~d})$ in the presence of $\mathrm{H}_{2} \mathrm{O}[\mathrm{II}]$.

\subsection{Role of $\mathrm{O}_{2}$ on the Photocatalytic Reactions}

When the half reaction for the photocatalytic hydroxylation of benzene was performed on the $\mathrm{Pt}-\mathrm{WO}_{3}$ in the presence of $\mathrm{Ag}^{+}$ions as electron scavenger instead of $\mathrm{O}_{2}$ under visible-light irradiation, no products could be detected under visible-light irradiation (Table 2). This result indicated that both $\mathrm{H}_{2} \mathrm{O}$ and $\mathrm{O}_{2}$ (air) in combination are essential for hydroxylation of benzene under visible-light irradiation. 
Table 2. Effects of $\mathrm{Ag}^{+}$ions added on the photocatalytic hydroxylation of benzene on the $\mathrm{Pt}(0.2)-\mathrm{WO}_{3}$ photocatalyst under photo-irradiation.

\begin{tabular}{ccccccccc}
\hline \multirow{2}{*}{$\begin{array}{c}\text { Reaction } \\
\text { Condition }\end{array}$} & PH & RE & $p$-BQ & CA & HQ & PL & PG & Selectivity of \\
PH/\%
\end{tabular}

The flat band potential of $\mathrm{WO}_{3}$ was obtained from capacitance versus voltage measurements. The $\mathrm{WO}_{3}$ powder was deposited on fluorine-doped tin oxide (FTO) coated glass. Mott-Schottky plots indicated that the flatband potential ( $\approx$ conduction band) of the $\mathrm{WO}_{3} / \mathrm{FTO}$ was estimated to be $+0.40 \mathrm{~V}$ vs. reversible hydrogen electrode (RHE) (Figure S3). LSV measurements of $\mathrm{WO}_{3}$ and $\mathrm{Pt}-\mathrm{WO}_{3}$ were carried out in $\mathrm{O}_{2}$-saturated $0.1 \mathrm{M} \mathrm{Na}_{2} \mathrm{SO}_{4}$ aq. The cathodic current was obtained at the potential more cathodic than the conduction band (+0.40 V vs. RHE) of $\mathrm{WO}_{3}$ (See Figure S4). This cathodic current would be attributed to the reduction of $\mathrm{WO}_{3}$. Furthermore, the cathodic current significantly increased by deposition of $\mathrm{Pt}$ on $\mathrm{WO}_{3}$. A deposition of $\mathrm{Pt}$ species as a co-catalyst caused an improvement of the ORR. It is noted that multi-electron reduction of $\mathrm{O}_{2}$ to $\mathrm{H}_{2} \mathrm{O}_{2}$, thermodynamically occurred at $E^{0}\left(\mathrm{O}_{2} / \mathrm{H}_{2} \mathrm{O}_{2}\right)=+0.68 \mathrm{~V}$ [33]. An increase of cathodic current is attributed to the effective electron transfer to $\mathrm{O}_{2}$ via $\mathrm{Pt}$ species to form $\mathrm{H}_{2} \mathrm{O}_{2}$ [34].

It was confirmed that the hydroxylation of benzene in the presence of $\mathrm{H}_{2} \mathrm{O}_{2}$ did not take place under photoirradiation without a photocatalyst nor with photocatalyst without irradiation. However, both photocatalyst and visible-light irradiation are required for the hydroxylation of benzene (See Table S4). In order to understand the role of $\mathrm{H}_{2} \mathrm{O}_{2}$, the hydroxylation of benzene ( $\left.300 \mu \mathrm{mol}\right)$ in the presence of $\mathrm{H}_{2} \mathrm{O}_{2}(150 \mu \mathrm{mol})$ and $\mathrm{H}_{2}{ }^{16} \mathrm{O}(90 \%) / \mathrm{H}_{2}{ }^{18} \mathrm{O}(10 \%)$ was conducted on the $\mathrm{Pt}^{-} \mathrm{WO}_{3}$ under visible-light irradiation. As a result, the ratio of ${ }^{18} \mathrm{O}$ to ${ }^{16} \mathrm{O}$ was determined to be $8.3 \%$, suggesting that major contribution of $\mathrm{OH}$ groups in phenol came from $\mathrm{H}_{2} \mathrm{O}$ even in the presence of $\mathrm{H}_{2} \mathrm{O}_{2}$.

\subsection{Reaction Mechanisms for Photocatalytic Hydroxylation of Benzene to Phenol}

In order to evaluate the oxidation power of photo-induced holes, photocatalytic half reactions on the $\mathrm{Pt}(0.2)-\mathrm{WO}_{3}$ photocatalyst were carried out. It was observed that addition of $\mathrm{Ag}^{+}$ions instead of $\mathrm{O}_{2}$ showed no products under visible-light irradiation, while the phenolic compounds were detected under UV-light irradiation (See Table 2). These results suggest that water oxidation by UV-light irradiation induced strong oxidation power possibly to form free $\mathrm{OH}$ radicals, which would attack benzene directly [29], but by visible-light irradiation would not form $\mathrm{OH}$ radicals. In fact, we employed the tertiary butyl alcohol (TBA) as scavengers of $\mathrm{OH}$ radicals. As a result, the TBA added in the photocatalytic system on the $\mathrm{Pt}-\mathrm{WO}_{3}$ under visible-light irradiation did not influence to the yields of phenol (Table 3). However, the amounts of catechol (CA) and phloroglucinol (PL) decreased by the addition of TBA (See Table 3). The di- and tri- $\mathrm{OH}$ groups involved in phenolic compounds may be partially derived from $\mathrm{O}_{2}$. Research is under way using an ${ }^{18} \mathrm{O}_{2}$ labeling test.

Table 3. Effects of tertiary butyl alcohol (TBA) added on the photocatalytic hydroxylation of benzene on the $\mathrm{Pt}(0.2)-\mathrm{WO}_{3}$ photocatalyst under visible light irradiation for $20 \mathrm{~h}$ under air.

\begin{tabular}{|c|c|c|c|c|c|c|c|c|}
\hline \multirow{2}{*}{ TBA Added/ $\mu \mathrm{mol}$} & \multicolumn{7}{|c|}{ Products/ $\mu \mathrm{mol}$} & \multirow{2}{*}{$\begin{array}{c}\text { Selectivity of } \\
\text { PH/\% }\end{array}$} \\
\hline & $\mathrm{PH}$ & RE & $\mathbf{B Q}$ & $\mathrm{CA}$ & HQ & PL & PG & \\
\hline 0 & 29.0 & 1.2 & 0.19 & 18.3 & 0.34 & 19 & 2.4 & 41.0 \\
\hline 50 & 29.2 & 1.39 & 0.25 & 13.3 & 0.27 & 7.9 & 5.0 & 51.0 \\
\hline
\end{tabular}


As mentioned above, $\mathrm{H}_{2} \mathrm{O}_{2}$ was confirmed to form as intermediate species by multi-electron reduction of $\mathrm{O}_{2}$ during photocatalytic hydroxylation of benzene. The reaction mechanisms were investigated by DFT calculations. Figure 5 [Ia] showed the optimized structures of the reactant, transitional state (TS) and product by the interactions of benzene, $\mathrm{H}_{2} \mathrm{O}$ with $\mathrm{H}_{2} \mathrm{O}_{2}$. The $\mathrm{O}-\mathrm{H}$ bond length in $\mathrm{H}_{2} \mathrm{O}, \mathrm{O}-\mathrm{O}$ in $\mathrm{H}_{2} \mathrm{O}_{2}$ and $\mathrm{C}-\mathrm{H}$ in benzene were observed to increase through the reaction path. It was found that $\mathrm{H}_{2} \mathrm{O}_{2}$ could assist $\mathrm{C}-\mathrm{H}$ bond dissociation from benzene. Subsequently, $\mathrm{OH}$ species derived from $\mathrm{H}_{2} \mathrm{O}$ was incorporated within phenol in the final product. Moreover, the reaction path in the presence of the Pt co-catalyst was investigated (See Figure 5 [Ib]). Strong interaction of $\mathrm{H}_{2} \mathrm{O}_{2}$ with $\mathrm{Pt}_{3}$ was observed to dissociate the $\mathrm{O}-\mathrm{O}$ bond to form $\mathrm{O}$ species, and subsequently, the $\mathrm{C}-\mathrm{H}$ bond in benzene was dissociated by an assist of the $\mathrm{O}$ species and/or $\mathrm{Pt}_{3}$. The energy changes for overall reactions were indicated in Figure 5 [II]. The hydroxylation of benzene proceeded on much lower potential energy surface with the $\mathrm{Pt}_{3}$ co-catalyst than that without $\mathrm{Pt}_{3}$ co-catalyst. Thus, we have demonstrated the possible reaction path for hydroxylation of benzene to form phenol including $\mathrm{OH}$ groups derived from $\mathrm{H}_{2} \mathrm{O}$.

(a)

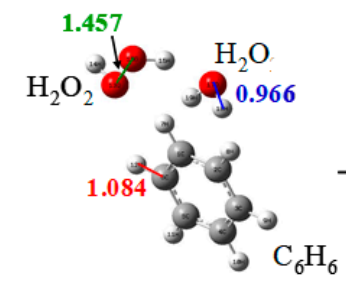

Reactant

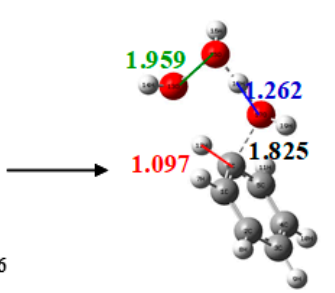

TS

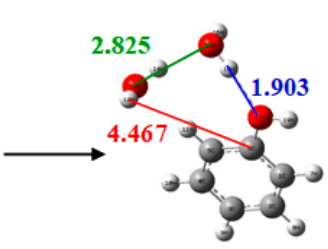

Products

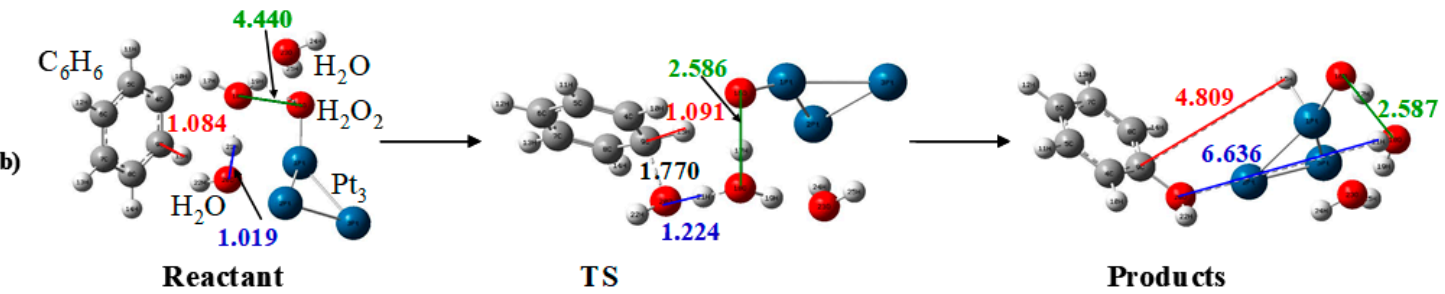

[I]

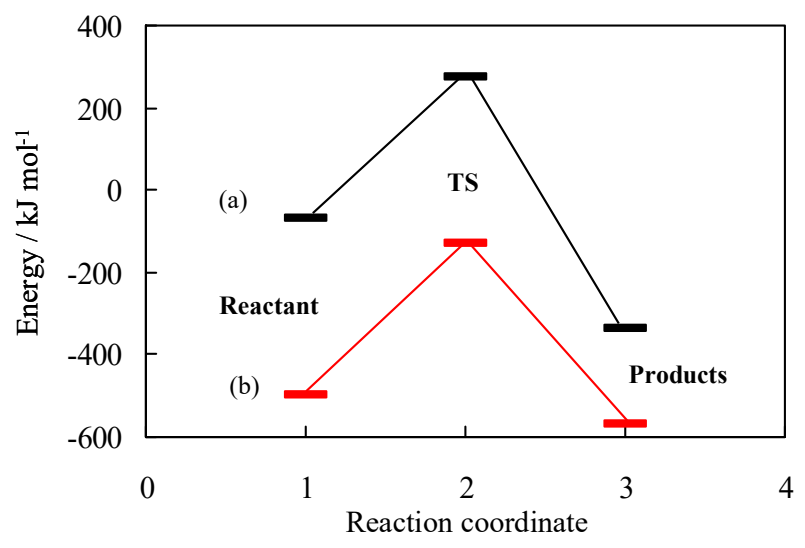

[II]

Figure 5. Optimized structures at the reactant, TS and product between benzene, $\mathrm{H}_{2} \mathrm{O}$ and $\mathrm{H}_{2} \mathrm{O}_{2}$ system in the absence [Ia] and presence [Ib] of $\mathrm{Pt}_{3}$ as co-catalyst for the hydroxylation of benzene to form phenol; and energy potentials for intrinsic reaction coordinates (IRC) [II]. The stabilization energy at each state was calculated by the difference from the energy of isolated system. The bond distance $(\AA)$ of $\mathrm{O}-\mathrm{H}$ in $\mathrm{H}_{2} \mathrm{O}$ (blue), $\mathrm{O}-\mathrm{O}$ in $\mathrm{H}_{2} \mathrm{O}_{2}$ (green) and $\mathrm{C}-\mathrm{H}$ in benzene (red) were indicated. 
The reaction mechanism for the direct hydroxylation of benzene to phenol on the $\mathrm{Pt}-\mathrm{WO}_{3}$ was proposed (See Figure 6). This reaction is initiated by visible-light irradiation of the $\mathrm{WO}_{3}$. The photo-induced holes and electrons are generated in the $\mathrm{VB}$ and $\mathrm{CB}$ of the $\mathrm{WO}_{3}$, respectively. It was assumed that the photo-induced holes can oxidize $\mathrm{H}_{2} \mathrm{O}$ to form $\mathrm{O}_{2}$ [1], as well as activated $\left(\mathrm{H}_{2} \mathrm{O}\right)^{*}$ intermediate species of which the $\mathrm{O}-\mathrm{H}$ bond length would be increased. On the other hand, the electrons effectively transfer from $\mathrm{CB}$ to $\mathrm{O}_{2}$ via Pt species to form peroxide species such as $\mathrm{H}_{2} \mathrm{O}_{2}$, which would be further activated on the catalyst surface. The activated $\left(\mathrm{H}_{2} \mathrm{O}\right)^{*}$ species would attack the $\pi$ electrons of the aromatic benzene ring, assisting the activated $\left(\mathrm{H}_{2} \mathrm{O}_{2}\right)^{*}$ to dissociate the $\mathrm{C}-\mathrm{H}$ bond in benzene. It was, thus, proposed that the hydroxylation of benzene occurs by a mechanism involving a push-pull process, which promotes the formation of phenol.

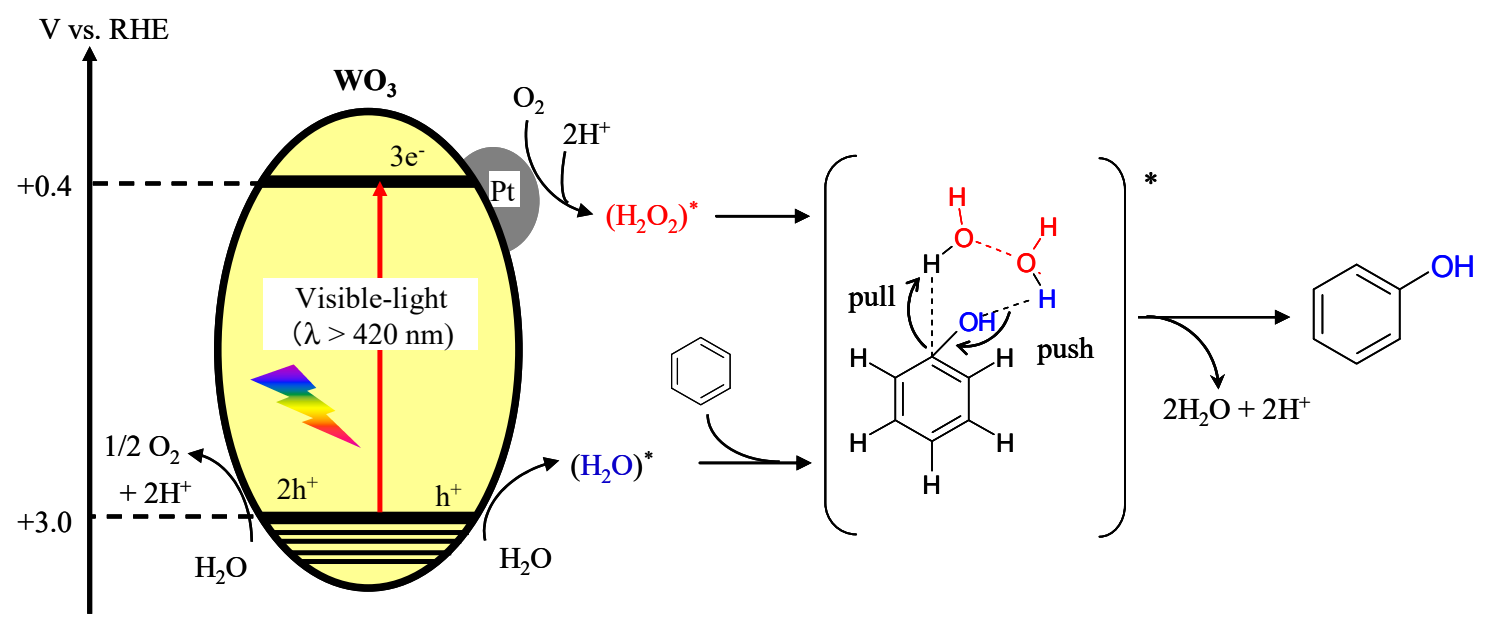

Figure 6. Reaction mechanisms for the hydroxylation of benzene into phenol in the presence of $\mathrm{O}_{2}$ and $\mathrm{H}_{2} \mathrm{O}$ on the $\mathrm{Pt}_{-} \mathrm{WO}_{3}$ under visible light irradiation. ( $\left.{ }^{*}\right)$ indicates formation of activated $\mathrm{H}_{2} \mathrm{O}$ and $\mathrm{H}_{2} \mathrm{O}_{2}$ intermediates by photo-excitation.

\section{Materials and Methods}

\subsection{Materials}

Tungsten trioxide $\left(\mathrm{WO}_{3}, 99.9 \%\right.$ ) from Kojundo Chemical Laboratory (Osaka, Japan), $\mathrm{H}_{2} \mathrm{PtCl}_{6} \cdot 6 \mathrm{H}_{2} \mathrm{O}$ (99.9\%) from Wako Pure Chemical Industries (Osaka, Japan); and water- ${ }^{18} \mathrm{O}\left(97\right.$ atom\% ${ }^{18} \mathrm{O}$ ) and titanium (IV) oxysulfate solution (99.99\%) from Sigma-Aldrich (St. Louis, MO, USA) were purchased. All chemicals were used without further purification.

\subsection{Photoelectrochemical Deposition of Pt Species as Co-Catalyst on the $\mathrm{WO}_{3}$}

Photoelectrochemical deposition of $\mathrm{Pt}$ species was conducted on the $\mathrm{WO}_{3}$ surface. $\mathrm{WO}_{3}$ powder $(1.0 \mathrm{~g})$ was suspended in distilled water $(25 \mathrm{~mL})$ involving desired amounts of $\mathrm{H}_{2} \mathrm{PtCl}_{6}$ $\left(4.32 \times 10^{-6} \sim 2.16 \times 10^{-5} \mathrm{~mol}\right)$, and the suspension was photo-irradiated by a light-emitting diode (LED) lamp $(420<\lambda<540 \mathrm{~nm})$ for $1 \mathrm{~h}$ under stirring in order to disperse photo-adsorbed Pt species. Subsequently, methanol $(5 \mathrm{~mL})$ as reductant was added into the suspension, and then it was continuously photo-irradiated for $4 \mathrm{~h}$. The solid products were separated by centrifuge (LC-200, TOMY, $4500 \mathrm{rpm}$ ), followed by washing with distilled water and acetonitrile, and drying under vacuum condition at ambient temperature over night. The photocatalyst was referred to be as $\mathrm{Pt}(\mathrm{x})-\mathrm{WO}_{3}(\mathrm{x}:$ atom\%). The photocatalyst was kept in the ambient temperature, and the photocatalytic reactions were carried out without further treatment of photocatalyst. 


\subsection{Characterizations}

The X-ray diffraction (XRD) patterns were obtained with a RIGAKU RINT2000 using Cu $\mathrm{K}_{\alpha}$ radiation $(\lambda=1.5417 \AA)$ (RIGAKU, Tokyo, Japan). The oxidative states of Pt species were analyzed by an X-ray photoelectron spectroscope (XPS), KRATOS, AXIS Ultra, using Al $\mathrm{K}_{\alpha}$ radiation $(E=1486.8 \mathrm{eV})$ (Shimadzu, Kyoto, Japan). The UV-Vis spectroscopic measurements were carried out on diffuse reflectance with a UV-Vis scanning spectrophotometer (UV-3100PC, Shimadzu, Kyoto, Japan). The elemental distribution images were taken with scanning transmittance electron microscope with energy-dispersed X-ray emission spectroscopy (STEM-EDS; JEOL JSM-2100, Tokyo, Japan).

\subsection{Photocatalytic Reactions}

Photocatalyst $(20 \mathrm{mg})$ was suspended in distilled water $(2,5$ or $10 \mathrm{~mL})$ in a pyrex reaction tube (volume: $20 \mathrm{~mL}$ ) under air capped with precision seal septum. If specific description was not given, the distilled water $(10 \mathrm{~mL})$ was introduced. And subsequently, $26.8 \mu \mathrm{L}$ of benzene ( $300 \mu \mathrm{mol})$ was dropped into the suspension by a syringe under vigorous stirring. The reaction cell was photo-irradiated by a blue LED (visible light: $420<\lambda<540 \mathrm{~nm}$ ) or black light (UV light: $300<\lambda<400 \mathrm{~nm}$ ) at $298 \mathrm{~K}$. The light energy intensities were shown in Figure S5. After the reaction, the catalysts were immediately separated from the suspension by filtration through a $0.20 \mu \mathrm{m}$ membrane filter (Dismic-25JP, Advantec, Tokyo, Japan). The solution was, then, analyzed by High Performance Liquid Chromatography (HPLC, Shimadzu LC10ATVP, Kyoto, Japan, UV-Vis detector, column: Chemcopak, mobile phase: a mixture of acetonitrile and $1.0 \%$ formic acid aqueous solution), and several products were identified (see Figure S6). The gas phase $\left(\mathrm{CO}_{2}\right)$ was analyzed by Gas Chromatography-thermal conductivity detector (GC-TCD, Shimadzu GC-8A, Kyoto, Japan; column: porapak Q). Titanium sulfate (100 $\mu \mathrm{L})$ was added to $1 \mathrm{~mL}$ of the reaction solution, and amounts of $\mathrm{H}_{2} \mathrm{O}_{2}$ formed in solution were analyzed by colorimetry from the value of absorbance at $410 \mathrm{~nm}$ in the UV-Vis absorption spectrum.

For the tracer experiment, $\mathrm{H}_{2}{ }^{18} \mathrm{O}$ was used as the oxygen isotope source. The photocatalytic hydroxylation of benzene or phenol was carried out over $\mathrm{Pt}^{-\mathrm{WO}_{3}}$ photocatalyst in the presence of $\mathrm{H}_{2}{ }^{18} \mathrm{O}(10 \%) / \mathrm{H}_{2}{ }^{16} \mathrm{O}(90 \%)$ as solvent and air under visible-light irradiation for $20 \mathrm{~h}$. The photocatalytic hydroxylation of benzene was performed in the presence of $\mathrm{H}_{2}{ }^{16} \mathrm{O}_{2}(100 \mu \mathrm{mol})$ and $\mathrm{H}_{2}{ }^{18} \mathrm{O}(10 \%) / \mathrm{H}_{2}{ }^{16} \mathrm{O}$ $(90 \%)$ under visible-light irradiation for $2 \mathrm{~h}$. Phenol in aqueous solutions were extracted by toluene, and the molar ratios of $\mathrm{Ph}^{-18} \mathrm{OH}$ and $\mathrm{Ph}^{-16} \mathrm{OH}$ were identified by LC-MS (Shimadzu LCMS-2020 spectrometer, Kyoto, Japan).

\subsection{Electrochemical Measurements}

Flatband potentials of the photoelectrodes were measured by a Potentio/Galvanostat (PGSTAT204, Autolab). The electrolysis cell was constructed with three electrodes, the $\mathrm{WO}_{3}$ photoelectrode as working electrode, the platinum wire as auxiliary, and $\mathrm{Ag} / \mathrm{AgCl}$ as the reference electrode. The $\mathrm{WO}_{3}$ photoelectrodes were prepared as follows: the $\mathrm{WO}_{3}(20 \mathrm{mg})$ was suspended in ethanol $(0.2 \mathrm{~mL})$ by a super-sonification to form a paste. The paste was then spread onto the FTO (active space $1.0 \mathrm{~cm}^{2}$, Aldrich) by spin coating (2200 rpm, $30 \mathrm{~s}$ ) for 3 times, followed by heat-treatment at $773 \mathrm{~K}$ for $1 \mathrm{~h}$ in air. Prior to measurements, $0.10 \mathrm{M} \mathrm{Na}_{2} \mathrm{SO}_{4}$ aqueous solution was vigorously bubbled by $\mathrm{N}_{2}$ gas for $20 \mathrm{~min}$ in order to remove $\mathrm{O}_{2}$.

Linear sweep voltammetry (LSV) was conducted at the rate of $10 \mathrm{mV} \mathrm{s}^{-1}$. The photocatalyst $(20 \mathrm{mg}$ ) was added into ethanol $(0.2 \mathrm{~mL})$, followed by a super-sonification for $5 \mathrm{~min}$ to disperse. The paste was casted by spin-coating ( $2200 \mathrm{rpm}, 30 \mathrm{~s}$ ) on the conductive transparent glass (FTO, $10 \Omega / \square$, Sigma Aldrich, St. Louis, MO, USA) 3 times, followed by heat-treatment at $373 \mathrm{~K}$ overnight. Prior to LSV measurements, $0.10 \mathrm{M} \mathrm{Na}_{2} \mathrm{SO}_{4}$ aq. was vigorously bubbled by $\mathrm{O}_{2}$ for $20 \mathrm{~min}$. 


\subsection{Density Functional Theory (DFT) Calculation}

Gaussian 09 program [35] and the hybrid B3LYP functional [36] were used. For Pt atoms, the Los Alamos effective core potentials [37] were employed along with the corresponding valence double basis sets [38]. For other atoms, a 6-311G(d,p) basis set was used. After the transition state (TS) was characterized, the intrinsic reaction coordinate (IRC) analysis [39] was carried out for both directions, reactant and product sides. The IRC analyses were followed by normal optimization runs, and the reactant and product were optimized as local minima.

\section{Conclusions}

In this study, we provided an understanding of photocatalytic activities for the hydroxylation of benzene under irradiation of only visible-light $(420<\lambda<540 \mathrm{~nm})$. It was demonstrated that hydroxylation of benzene on the $\mathrm{Pt}_{-} \mathrm{WO}_{3}$ photocatalyst in the presence of air and $\mathrm{H}_{2} \mathrm{O}$ produced several products such as phenol, catechol and phloroglucinol etc., and the selectivity of phenol improved over $70 \%$.

One of novelties in our findings was to confirm the reaction mechanisms for photocatalytic hydroxylation of benzene into phenol by experimental and theoretical studies. An investigation of the mechanistic insights has been carried out by the combination with apparent quantum yields (AQY), an $\mathrm{H}_{2}{ }^{18} \mathrm{O}$ isotope-labeling experiment, kinetic isotope effects $\left(\mathrm{C}_{6} \mathrm{D}_{6}, \mathrm{D}_{2} \mathrm{O}\right)$, electrochemical measurements, and DFT calculations. It was proposed that the substitution of the $\mathrm{OH}$ derived from $\mathrm{H}_{2} \mathrm{O}$ with $\mathrm{H}$ abstracted from benzene by photo-formed $\mathrm{H}_{2} \mathrm{O}_{2}$ indicated a mechanism involving a push-pull process for the hydroxylation of benzene into phenol. Our results showed new perspectives for the enhancement of yields and selectivity of phenol, as well as deeper understanding of the reaction mechanisms for the hydroxylation of benzene into phenol on the $\mathrm{Pt}_{-} \mathrm{WO}_{3}$ photocatalyst.

Supplementary Materials: The following are available online at http://www.mdpi.com/2073-4344/10/5/557/s1: Figure S1: Tauc plots of $\mathrm{WO}_{3}$, Figure S2: $\mathrm{H}_{2}{ }^{18} \mathrm{O}$ isotope labeling experiments, Figure S3: Mott-Schottky plots of $\mathrm{WO}_{3}$, Figure S4: LSV measurements of $\mathrm{WO}_{3}$ and $\mathrm{Pt}_{-} \mathrm{WO}_{3}$, Figure S5: Photo-intensities emitted from light-emitting diode (LED) and UV lamp, Figure S6: Molecular structures of products, Table S1: Photocatalytic activities depending on the amounts of Pt-deposition, Table S2: Time profiles in the photocatalytic reaction, Table S3: Effects of volumes in the reaction on the photocatalytic activity, Table S4: Role of $\mathrm{H}_{2} \mathrm{O}_{2}$ for the photocatalytic reactions.

Author Contributions: Conceptualization, S.H.; investigation, Y.K., M.T.; writing-original draft preparation, Y.K.; writing-review and editing, S.H., Y.S., H.K., M.M., Y.M.; supervision, S.H.; project administration, S.H. All authors have read and agreed to the published version of the manuscript.

Funding: This research received no external funding.

Conflicts of Interest: The authors declare no conflict of interest.

\section{References}

1. Wang, Y.; Suzuki, H.; Xie, J.; Tomita, O.; Martin, D.J.; Higashi, M.; Kong, D.R.; Abe, R.; Tang, J. Mimicking natural photosynthesis: Solar to renewable $\mathrm{H}_{2}$ fuel synthesis by Z-scheme water splitting systems. Chem. Rev. 2018, 118, 5201-5241. [CrossRef] [PubMed]

2. Schneider, J.; Matsuoka, M.; Takeuchi, M.; Zhang, J.; Horiuchi, Y.; Anpo, M.; Bahnemann, D.W. Understanding $\mathrm{TiO}_{2}$ photocatalysis: Mechanisms and materials. Chem. Rev. 2014, 114, 9919-9986. [CrossRef] [PubMed]

3. Ma, Y.; Wang, X.; Jia, Y.; Chen, X.; Han, H.; Li, C. Titanium dioxide-based nanomaterials for photocatalytic fuel generations. Chem. Rev. 2014, 114, 9987-10043. [CrossRef] [PubMed]

4. Kou, J.; Lu, C.; Wang, J.; Chen, Y.; Xu, Z.; Varma, R.S. Selectivity enhancement in heterogeneous photocatalytic transformations. Chem. Rev. 2017, 117, 1445-1514. [CrossRef] [PubMed]

5. Yamashita, H.; Mori, K.; Kuwahara, Y.; Kamegawa, T.; Wen, M.; Verma, P.; Che, M. Single-site and nano-confined photocatalysts designed in porous materials for environmental uses and solar fuels. Chem. Soc. Rev. 2018, 47, 8072-8096. [CrossRef]

6. Higashimoto, S. Titanium dioxide-based visible-light sensitive photocatalysis: Mechanistic insight and applications. Catalysts 2019, 9, 201. [CrossRef] 
7. Asahi, R.; Morikawa, T.; Irie, H.; Ohwaki, T. Nitrogen-doped titanium dioxide as visible light-sensitive photocatalyst: Designs, developments, and prospects. Chem. Rev. 2014, 114, 9824-9852. [CrossRef]

8. Abe, R.; Takami, H.; Murakami, N.; Ohtani, B. Pristine simple oxides as visible light driven photocatalysts: Highly efficient decomposition of organic compounds over platinum-loaded tungsten oxide. J. Am. Chem. Soc. 2008, 130, 7780-7781. [CrossRef]

9. Arai, T.; Horiguchi, M.; Yanagida, M.; Gunji, T.; Sugihara, H.; Sayama, K. Reaction mechanism and activity of $\mathrm{WO}_{3}$-catalyzed photodegradation of organic substances promoted by a $\mathrm{CuO}$ cocatalyst. J. Phys. Chem. C 2009, 113, 6602-6609. [CrossRef]

10. Arai, T.; Horiguchi, M.; Yanagida, M.; Gunji, T.; Sugihara, H.; Sayama, K. Complete oxidation of acetaldehyde and toluene over a $\mathrm{Pd} / \mathrm{WO}_{3}$ photocatalyst under fluorescent- or visible-light irradiation. Chem. Commun. 2008, 43, 5565-5567. [CrossRef]

11. Tomita, O.; Sugimoto, T.; Sako, K.; Hayakawa, S.; Katagiri, K.; Inumaru, K. Enhanced photocatalytic activity of $\mathrm{Pt} / \mathrm{WO}_{3}$ photocatalyst combined with $\mathrm{TiO}_{2}$ nanoparticles by polyelectrolyte-mediated electrostatic adsorption. Catal. Sci. Technol. 2015, 5, 1163-1168.

12. Higashimoto, S.; Katsuura, K.; Yamamoto, M.; Tahakashi, M. Photocatalytic activity for decomposition of volatile organic compound on $\mathrm{Pt}_{-} \mathrm{WO}_{3}$ enhanced by simple physical mixing with $\mathrm{TiO}_{2}$. Catal. Commun. 2020, 133, 105831. [CrossRef]

13. Higashimoto, S.; Ushiroda, Y.; Azuma, M. Electrochemically assisted photocatalysis of hybrid $\mathrm{WO}_{3} / \mathrm{TiO}_{2}$ films: Effect of the $\mathrm{WO}_{3}$ structures on charge separation behavior. Top. Catal. 2008, 47, 148-154. [CrossRef]

14. Tomita, O.; Otsubo, T.; Higashi, M.; Ohtani, B.; Abe, R. Partial oxidation of alcohols on visible-light-responsive WO3 photocatalysts loaded with palladium oxide cocatalyst. ACS Catal. 2016, 6, 1134-1144. [CrossRef]

15. Niwa, S.; Eswaramoorthy, M.; Nair, J.; Raj, A.; Ito, N.; Shoji, H.; Nanba, T.; Mizukami, F. A one-step conversion of benzene to phenol with a palladium membrane. Science 2002, 295, 105-107. [CrossRef]

16. Tanev, P.T.; Chibwe, M.; Pinnavaia, T.J. Titanium-containing mesoporous molecular sieves for catalytic oxidation of aromatic compounds. Nature 1994, 368, 321-323. [CrossRef]

17. Chen, J.; Gao, S.; Xu, J. Direct hydroxylation of benzene to phenol over a new vanadium-substituted phosphomolybdate as a solid catalyst. Catal. Commun. 2008, 9, 728-733. [CrossRef]

18. Ohkubo, K.; Kobayashi, T.; Fukuzumi, S. Direct oxygenation of benzene to phenol using quinolinium ions as homogeneous photocatalysts. Angew. Chem. Int. Ed. 2011, 50, 8652-8655. [CrossRef]

19. Fukuzumi, S.; Ohkubo, K. One step selective hydroxylation of benzene to phenol. Asian J. Org. Chem. 2015, 4, 836-845. [CrossRef]

20. Han, J.W.; Jung, J.; Lee, Y.M.; Nam, W.; Fukuzumi, S. Photocatalytic oxidation of benzene to phenol using dioxygen as an oxygen source and water as an electron source in the presence of a cobalt catalyst. Chem. Sci. 2017, 8, 7119-7125. [CrossRef]

21. Fukuzumi, S.; Lee, Y.M.; Nam, W. Photocatalytic oxygenation reactions using water and dioxygen. ChemSusChem 2019, 12, 3931-3940. [CrossRef] [PubMed]

22. Yoshida, H.; Yuzawa, H.; Aoki, M.; Otake, K.; Itoh, H.; Hattori, T. Photocatalytic hydroxylation of aromatic ring by using water as an oxidant. Chem. Commun. 2008, 38, 4634-4636. [CrossRef] [PubMed]

23. Bui, T.D.; Kimura, A.; Ikeda, S.; Matsumura, M. Determination of oxygen sources for oxidation of benzene on $\mathrm{TiO}_{2}$ photocatalysts in aqueous solutions containing molecular oxygen. J. Am. Chem. Soc. 2010, 132, 8453-8458. [CrossRef] [PubMed]

24. Ide, Y.; Matsuoka, M.; Ogawa, M. Efficient visible-light-induced photocatalytic activity on gold-nanoparticle-supported layered titanate. J. Am. Chem. Soc. 2010, 47, 16762-16764. [CrossRef]

25. Ide, Y.; Torii, M.; Sano, T. Layered silicate as an excellent partner of a $\mathrm{TiO}_{2}$ photocatalyst for efficient and selective green fine-chemical synthesis. J. Am. Chem. Soc. 2013, 135, 11784-11786. [CrossRef]

26. Zheng, Z.; Huang, B.; Qin, X.; Zhang, X.; Dai, Y.; Whangbo, M.-H. Facile in situ synthesis of visible-light plasmonic photocatalysts $\mathrm{M} @ T i O_{2}(\mathrm{M}=\mathrm{Au}, \mathrm{Pt}, \mathrm{Ag})$ and evaluation of their photocatalytic oxidation of benzene to phenol. J. Mater. Chem. 2011, 21, 9079-9087. [CrossRef]

27. Goto, T.; Ogawa, M. Efficient photocatalytic oxidation of benzene to phenol by metal complex-clay/TiO 2 hybrid photocatalyst. RSC Adv. 2016, 6, 23794-23797. [CrossRef]

28. Tomita, O.; Abe, R.; Ohtani, B. Direct synthesis of phenol from benzene over platinum-loaded tungsten(VI) oxide photocatalysts with water and molecular oxygen. Chem. Lett. 2011, 40, 1405-1407. [CrossRef] 
29. Tomita, O.; Ohtani, B.; Abe, R. Highly selective phenol production from benzene on a platinum-loaded tungsten oxide photocatalyst with water and molecular oxygen: Selective oxidation of water by holes for generating hydroxyl radical as the predominant source of the hydroxyl group. Catal. Sci. Technol. 2014, 4, 3850-3860. [CrossRef]

30. Chen, C.W.; Tano, D.; Akashi, M. Synthesis of platinum colloids sterically stabilized by poly( $N$-vinylformamide) or poly( $N$-vinylalkylamide) and their stability towards salt. Colloid Polym. Sci. 1999, 277, 488-493. [CrossRef]

31. Arabatzis, I.M.; Stergiopoulos, T.; Andreeva, D. Characterization and photocatalytic activity of $\mathrm{Au} / \mathrm{TiO}_{2}$ thin films for azo-dye degradation. J. Catal. 2003, 220, 127-135. [CrossRef]

32. Buchachenko, A.L.; Dubinina, E.O. Photo-oxidation of water by molecular oxygen: Isotope exchange and isotope effects. J. Phys. Chem. A 2011, 115, 3196-3200. [CrossRef] [PubMed]

33. Pourbaix, M. Atlas of Electrochemical Equilibria in Aqueous Solutions; Pergamon Press Ltd.: London, UK, 1966.

34. Panchenko, A.; Koper, M.T.M.; Shunbina, T.E.; Mitchell, S.J.; Roduner, E. Ab Initio calculation of intermediates of oxygen reduction on low-index platinum surfaces. J. Electrochem. Soc. 2004, 151, A2016-A2027. [CrossRef]

35. Frisch, M.J.; Trucks, G.W.; Schlegel, H.B.; Scuseria, G.E.; Robb, M.A.; Cheeseman, J.R.; Scalmani, G.; Barone, V.; Mennucci, B.; Petersson, G.A.; et al. Gaussian 09; Revision D.01; Gaussian, Inc.: Wallingford, CT, USA, 2013.

36. Becke, A.D. A new mixing of Hartree-Fock and local density-functional theories. J. Chem. Phys. 1993, 98, 5648-5652. [CrossRef]

37. Hay, P.J.; Wadt, W.R. Ab initio effective core potentials for molecular calculations. Potentials for the transition metal atoms Sc to Hg. J. Chem. Phys. 1985, 82, 270-283. [CrossRef]

38. Dunning, T.H.; Hay, P.J.; Schaefer, H.F. Modern Theoretical Chemistry; Schaefer, H.F., III, Ed.; Plenum Press: New York, NY, USA, 1976; Volume 3, pp. 1-28.

39. Fukui, K.; Kato, S.; Fujimoto, H. Constituent analysis of the potential gradient along a reaction coordinate. Method and an application to methane + tritium reaction. J. Am. Chem. Soc. 1975, 97, 1-7. [CrossRef]

(C) 2020 by the authors. Licensee MDPI, Basel, Switzerland. This article is an open access article distributed under the terms and conditions of the Creative Commons Attribution (CC BY) license (http://creativecommons.org/licenses/by/4.0/). 